\section{Differential reporting of discriminatory experiences in Brazil and the United States}

\author{
Relatos diferenciados de experiências com \\ discriminação no Brasil e Estados Unidos
}

\section{Relatos diferenciados de experiencias con discriminación en Brasil y Estados Unidos}

Sarah Burgard 1

Debora de Pina Castiglione 2

Katherine Y. Lin 3

Aline A. Nobre 4

Estela M. L. Aquino 5

Alexandre C. Pereira 6

Isabela J. Martins Bensenor 7

Sandhi M. Barreto 8

Dora Chor 2

doi: 10.1590/0102-311X00110516

\begin{abstract}
There has been little cross-national comparison of perceived discrimination, and few studies have considered how intersectional identities shape perception of discriminatory treatment in different societies. Using data from the ELSABrasil, a study of Brazilian civil servants, and the Americans' Changing Lives Study, a nationally-representative sample of U.S. adults, we compare reports of lifetime discrimination among race-by-gender groups in each society. We also consider whether educational attainment explains any group differences, or if differences across groups vary by level of education. Results reveal higher lifetime discrimination experiences among Black respondents in both countries, especially Black men, than among Whites, and lower reports among White women than White men. Brown men and women also reported higher levels than White men in Brazil. For all race-by-gender groups in both countries, except Brazilian White men, reports of discrimination were higher among the more educated, though adjusting for educational differences across groups did not explain group differences. In Brazil, we found the greatest racial disparities among the college educated, while U.S. Black men were more likely to report discrimination than White men at all levels of education. Results reveal broad similarities across countries, despite important differences in their histories, and an intersectional approach contributed to identification of these similarities and some differences in discrimination experiences. These findings have implications for social and public health surveillance and intervention to address the harmful consequences of discrimination.
\end{abstract}

Social Discrimination; Ethnic Groups; Sexism 


\section{Introduction}

Perceived discrimination has been identified as a major public health issue, with consequences for physical and mental health ${ }^{1}$, and health behaviors 2 . Most of the extant research on perceived discrimination has been conducted in the United States, a society with a long history of institutionalized racial discrimination, but one that experienced a Civil Rights movement in the 1960s that led to legal restrictions on racial discrimination, and a need to monitor compliance with these new laws. Researchers in other societies have also begun to explore the prevalence of perceived racial discrimination in the context of their own distinctive social and legal histories around race, such as South Africa ${ }^{3}$ and Brazil 4,5,6,7. Brazil stands out as a society without racially-discriminatory laws after the abolition of slavery, and a unique reputation as a supposed "racial democracy" as compared to other multiracial societies, but only recently has begun to officially acknowledge the persistence of racebased inequalities and discrimination. For example, the Secretary of Politics for the Promotion of Racial Equality was created in 2003, with the status of a Ministry.

Increasingly available evidence from Brazil does show evidence of racial disparity in perceived discrimination. A 2010 sample of adults in Belo Horizonte (Minas Gerais State) showed that 15\% of Blacks felt they were victim of any type of discrimination, compared to about $8 \%$ of Brown or White Brazilians 4. A higher percentage of Black and Brown adolescents in Pelotas (Rio Grande do Sul State) reported that during the past year from interview, they felt discriminated against or damaged because of "color or race; religion or cult; poverty or wealth; disease or physical disability" as compared to white peers 5 . A nationally-representative sample showed that self-identified Black Brazilians reported higher levels of racial discrimination (37\%) than Browns (10\%) or Whites (6.7\%), with similar race gaps whether interviewer-classified race or respondent self-classification was used ${ }^{7}$. Finally, Black and Brown university students in Rio de Janeiro reported more discrimination that they attributed to their race - or a combination of multiple identities, including race - than did their White counterparts, while Whites reported more discrimination on the basis of class, age, and for other reasons 6 .

Results from the United States suggest similar racial differences as found in Brazil. About 34\% of respondents in a nationally-representative sample from the late 1990s reported at least one episode of discrimination, with Blacks (48.9\%) reporting more than Whites (30.9\%) 8. Williams et al. 9 found significantly higher everyday discrimination experiences among African Americans as compared to Whites in a regional sample of adults in the same period. Other, smaller samples of particular groups of African Americans have found extremely high levels of lifetime race-related discrimination in interpersonal settings and in institutions of education, healthcare, and elsewhere 10 and high likelihood of hearing disparaging racial remarks or insults 11. However, despite historical similarities and differences that have shaped race-related inequality, a social scientific tradition of cross-national comparison of race relations 12,13,14, and evidence for racially-stratified experiences of discrimination in both societies, ours is among the first to compare the social distribution of perceived discrimination in Brazil and the United States.

In addition to a dearth of cross-national comparisons, there is only limited research that considers how intersectional identities shape perceptions of discrimination. Growing attention to intersectional identities provides an important corrective 15 and challenges the "...tendency to treat race and gender as mutually exclusive categories of experience and analysis" 16 (p. 25). Intersectional analyses explore how the interactions between multiple identities, such as race, gender and social class, may result in exposure to distinct patterns of oppression that are not simply equal to the quantity of risk summed across the total number of subordinate identities 17 , suggesting the importance of comparative research.

A small number of U.S. studies show that considering intersectional identities yields a more complex picture. A majority of African American college students at predominantly white universities experienced high levels of racial hassles, but male African American students reported higher levels than their female counterparts 18. African American men have reported more discrimination than African American women in other studies, though it is possible that standard measures of lifetime discrimination capture experiences more frequently experienced by men 19 . In the present study, we assess perceived lifetime discrimination among Brazilian and U.S. adults, considering differences across race, gender, and race-by-gender groups. Our research questions ask first, how is perceived discrimination distributed across race and gender groups in the US and Brazil? 
Second, are there intersectional race-by-gender patterns in reports of discrimination in either or both countries?

Moreover, given the complex interplay between race and social class standing, and the way this may vary across societies, we consider how educational attainment may account for or modify raceby-gender group differences in perceived discrimination. Some U.S. evidence suggests that those with more education perceive more discrimination. In a study of adult African American women, levels of lifetime and everyday discrimination were higher among those with some college or more than among those with high school or less 20 . Educational attainment is an important marker of social class in both societies, and we explore two ways in which education may influence patterns of perceived discrimination. Our third question asks: do differences in average educational attainment across groups account for race-gender differences in perceived discrimination? In other words, do differences in average levels of education across these groups, and differential experiences of discrimination among more or less educated people, mean that educational attainment is a mediator? Our final question asks: do race-by-gender patterns in perceived discrimination differ across levels of education? In other words, is education an effect modifier, with race-by-gender differences sharper among more or less advantaged groups? Though we endeavour to make as careful a comparison of Brazilian and U.S. adults as possible with our data, the measurement and meaning of race and other identities varies in large and small ways across contexts, so we conduct analyses for each in parallel.

\section{Data and methods}

\section{Data}

The Brazilian Longitudinal Study of Adult Health (ELSA-Brasil) is a multicenter cohort study designed to estimate the incidence of cardiovascular diseases and diabetes, as well as their main social, environmental, occupational and biological determinants, and has been described in detail elsewhere 21,22 . The 15,105 participants were recruited from 35 to 74 year old employed or retired civil servants at teaching and research institutions in six Brazilian cities (Rio de Janeiro, São Paulo, Vitória, Belo Horizonte, Salvador, and Porto Alegre). Baseline assessment took place from 2008 to 2010 via in-person interviews, clinical exams and laboratory tests $21,22,23,24$.

The Americans' Changing Lives Study (ACL) is a panel study initiated in 1986 with a multistage stratified area probability sample of non-institutionalized adults 25 or older living in the coterminous United States. Blacks and those aged 60 and older were over-sampled. The Wave 1 data were collected using face-to-face interviews with 3,617 participants (representing 70\% of sampled households and $68 \%$ of sampled individuals). Follow-up face-to-face or telephone interviews were collected in 1989 $(\mathrm{N}=2,867), 1994(\mathrm{~N}=2,559), 2001 / 2002(\mathrm{~N}=1,787)$, and $2011(\mathrm{~N}=1,427)$. We use data from Wave 4 (2001/2002), collected mainly via telephone, because it contained the most information about discriminatory experiences 25 .

Participants from the ELSA-Brasil study aged 40 and older at recruitment were included in our analytic sample $(N=13,949)$, to match the age range of participants in Wave 4 of ACL. We included participants who self-declared their race as "Black" or "White", and participants from the ELSA-Brasil study in the "Pardo" (Brown) racial category. Self-declared "Indigenous" $(\mathrm{N}=157)$ or "Yellow" ( $\mathrm{N}=$ 374) ELSA-Brasil participants and "Hispanic White" $(\mathrm{N}=49)$, "Hispanic Black" $(\mathrm{N}=6)$ and ACL participants of other race groups $(\mathrm{N}=50)$ were excluded from the analysis because their group sizes were too small. After these exclusions and dropping a small number of ELSA respondents missing on covariates, the final analytic samples were made up of 13,247 respondents from ELSA-Brasil and 1,680 from ACL. 


\section{Measures}

\section{- Perceived discrimination}

The two studies used different variations of the Major Experiences of Discrimination Scale to capture lifetime discrimination experiences ${ }^{3}$. ELSA-Brasil collected information using a stem question "Have you ever been unfairly treated, due to discrimination", that was followed up with five possible domains: (1) "at your workplace, for example, by getting fired, or promoted, or while applying for a job?”, (2) “...while searching for housing or interacting with neighbors?”, (3) “...by the police, such as being accused, searched or arrested?”, (4) “...in public places, such as banks, shops, hospitals, government offices, etc.?”, and (5) “...in your school or college, for example, being discouraged to continue your studies?”. The ACL Wave 4 questionnaire used a stem statement: "In the following questions, we are interested in your perceptions about the way other people have treated you. Can you tell me if any of the following has ever happened to you?". This statement was followed by questions about four domains: (1) "At any time in your life, have you ever been unfairly fired from a job or been unfairly denied a promotion?", (2) "For unfair reasons, have you ever not been hired for a job?", (3) "Have you ever been unfairly stopped, searched, questioned, physically threatened or abused by the police?", and (4) "Have you ever been unfairly prevented from moving into a neighborhood because the landlord or a realtor refused to sell or rent you a house or apartment?". In both studies, respondents who indicated "yes" to an item were coded as having reported an experience of discrimination, and we created an indicator of "any discrimination" if respondents reported at least one episode of discrimination in any domain included in that study's scale.

\section{- Race}

ELSA-Brasil asked respondents to self-declare race: "The Brazilian census (IBGE) uses the categories 'black, brown, white, yellow, indigenous' to classify a person's color or race. If you had to answer to the Brazilian census today, how would you declare your color or race?”. ACL collected data on race at baseline in 1986 with several items. Participants were asked "Are you of Spanish or Hispanic descent, that is, Mexican, Mexican American, Chicano, Puerto Rican, Cuban, or other Spanish?”. Respondents were also allowed an open-ended response to the question, "In addition to being American, what do you think of as your ethnic background or origins?". Respondents were then asked “Are you white, black, American Indian, Asian, or another race?" and allowed to choose one or more categories. Those who responded with more than one non-white group were asked to identify which "best described" their race. Finally, the survey also assessed the state or foreign country in which the respondent was born, respondent's mother, and respondent's father were born, and the respondent's father's last name. Responses from all of these questions were used to construct race categories of "Non-Hispanic White", "Non-Hispanic Black", "Non-Hispanic Native American”, "Non-Hispanic Asian”, and "Hispanic".

\section{- Gender}

While we recognize that gender and gender identity are crucial axes of inequality and are socially informed constructs that encompass more than biological sex, we are limited to using a measure of sex in these analyses, obtained for ELSA-Brasil participants from records from the universities and research institutions where they were recruited, and for ACL respondents from self-report at the baseline interview. Options of male or female were used in both studies.

\section{- Education}

We use education as our measure of social class because it is fixed early in life for many individuals, its interpretation generally stays stable as they age, its value does not change when people retire, it does not require that an individual is employed, and it is easier to compare across societal contexts than are many other aspects of social class. Educational attainment was obtained from respondent self-report at baseline in both studies. ELSA-Brasil respondents were asked about their highest grade of school obtained (from never attended through more than bachelor's degree - BA) and answers were 
aggregated into three categories: less than high school (13.7\%), high school or some college (35.7\%), and BA or more (50.6\%). ACL respondents were asked about the highest grade of school or year of college they completed, and whether they have a high school diploma and/or bachelor's degree, and respondents were aggregated into three categories: less than high school (17.4\%), high school or some college (60\%), bachelor's level degree or more (22.6\%).

\section{- Age}

Date of birth was obtained from administrative records for ELSA-Brasil respondents, converted to age in years and confirmed with respondents, and age was obtained from ACL respondent selfreports at baseline in 1986 .

\section{Statistical analysis}

We first calculated the frequency of reporting at least one episode of lifetime perceived discrimination, stratifying by respondent's race, gender, and educational attainment, and tested for significant group differences, with p-values obtained from chi-square tests of difference across groups. The significance threshold was set at $\mathrm{p}<0.05$. We then estimated a series of logistic regression models, using two different strategies to assess the impact of the focal social identities. We first estimated models with gender and race categories as separate predictor variables, to test our first research question. Then we capture the intersection of race and gender identities more directly than simply adjusting for each identity independently, as in the first models, and test our second research question by estimating models that include these main effects and also the interaction between them. To do so, we use a categorical measure capturing race-by-gender categories: White men (omitted as the most socially-privileged group), Brown men and Brown women (for Brazil only), and Black men and Black women. For each of these two approaches, we compare results before and after adjustment for education, to answer our third research question about education as a mediator. In a final step to test our fourth research question about effect modification, we estimated models that interacted educational categories with the race-by-gender categories. From this last set of models, we calculated odds ratios $(\mathrm{OR})$ and confidence intervals that allow us to compare the odds of reporting discrimination for other race-by-gender groups, compared to the odds for White men, among individuals with the same level of education. The $95 \%$ confidence intervals $(95 \% \mathrm{CI})$ for these comparisons were calculated using the covariance matrix of the model. For instance, the confidence interval for the OR for Black men with high school or some college compared to White men with the same education considers the variance of the coefficient for Black men, the variance of the interaction term between Black men and high school or some college, and the covariance between these two coefficients.

Analyses were conducted using the "stats" library of R version 2.15 (The R Foundation for Statistical Computing, Vienna, Austria; http://www.r-project.org) for ELSA-Brasil, and Stata/SE version 13 (StataCorp LP, College Station, USA) for ACL. Analyses accounted for study design and sample attrition for the ACL cohort using the "svy" commands in Stata.

\section{Results}

Table 1 presents descriptive statistics for each analytic sample. A similar fraction of ELSA and ACL respondents were male (45-46\%), but the racial composition of each sample was distinctive, as could be expected from these societies' different social, demographic and legal histories. Just over half of the Brazilian respondents identified as White, $29 \%$ as Brown, and $17 \%$ as Black, while $89 \%$ of the U.S. respondents identified as White and $11 \%$ as Black. Brazilian respondents were also more educated than those in the U.S., a function of the sample design, since ELSA participants are civil servants (many of whom have high educational attainment compared to the population overall) while ACL covered the entire U.S. population. About 14\% of ELSA respondents had less than a high school education, 35\% had high school or some college, and $51 \%$ had a BA or more, while the equivalent percentages for ACL 


\section{Table 1}

Sociodemographic characteristics of analytic samples: Brazilian Longitudinal Study of Adult Health (ELSA-Brasil) and Americans' Changing Lives Study (ACL).

\begin{tabular}{lcc}
\hline Characteristics & ELSA-Brasil (Brazil) & ACL (United States) \\
\hline Males (\%) & 45.5 & 45.2 \\
Race (\%) & 54.2 & 89.2 \\
$\quad$ White & 28.9 & $\mathrm{~N} / \mathrm{A}$ \\
$\quad$ Brown & 16.9 & 10.8 \\
$\quad$ Black & & \\
Educational attainment (\%) & 13.5 & 17.4 \\
$\quad$ Less than high school & 35.2 & 60.0 \\
High school or some college & 51.3 & 22.6 \\
$\quad$ BA or more & $52.0(51.95-52.23)$ & $57.5(56.6-58.4)$ \\
Age (mean and 95\%Cl) & 13,247 & 1,680 \\
N &
\end{tabular}

95\% Cl: 95\% confidence interval; BA: bachelor's degree; N/A: not available.

Note: ELSA sample includes respondents at least 40 years of age at baseline to match age range of $A C L$ respondents at Wave 4 .

Table 2

Percent of respondents reporting at least one episode of lifetime discrimination, and count of respondents in each category, overall and by race and gender.

\begin{tabular}{|c|c|c|c|c|c|c|}
\hline & \multicolumn{2}{|c|}{ Women } & \multicolumn{2}{|c|}{ Men } & \multicolumn{2}{|c|}{ Overall } \\
\hline & $\%$ & $\mathbf{n}$ & $\%$ & $\mathbf{n}$ & $\%$ & $\mathbf{n}$ \\
\hline \multicolumn{7}{|c|}{ ELSA-Brasil $(N=13,247)$} \\
\hline White & 33.1 * & 3,865 & 33.6 * & 3,314 & 33.3 & 7,179 \\
\hline Brown & $35.1 *$, ** & 1,989 & $40.1 *, \star \star$ & 1,842 & 37.5 & 3,831 \\
\hline Black & $46.4 *, * \star$ & 1,360 & $50.4 *, \star \star$ & 877 & 48.0 & 2,237 \\
\hline Overall & 36.2 & 7,214 & 38.0 & 6,033 & 37.0 & 13,247 \\
\hline \multicolumn{7}{|c|}{$\operatorname{ACL}(N=1,680)$} \\
\hline White & $18.9 *, * \star$ & 766 & $29.4 * * \star *$ & 476 & 23.7 & 1,269 \\
\hline Black & $32.3 * * *$ & 300 & $56.8 *, * \star$ & 138 & 42.2 & 411 \\
\hline Overall & 20.4 & 1,066 & 32.1 & 614 & 25.7 & 1,680 \\
\hline
\end{tabular}

ACL: Americans' Changing Lives Study; ELSA-Brasil: Brazilian Longitudinal Study of Adult Health.

* $\mathrm{p}$-value $<0.05$ for comparisons within gender groups, across race groups;

** $p$-value $<0.05$ for comparisons within race groups, across gender groups.

respondents were $17 \%, 60 \%$, and $23 \%$, respectively. At the time they reported on lifetime discrimination, Brazilian respondents were about 52 years old on average, and U.S. respondents were almost 58

Table 2 shows the percent reporting lifetime discrimination for race-by-gender groups, by gender, race, and overall. Among ELSA-Brasil respondents in the top panel, we find differences by race for both men and women. Black and Brown men report more lifetime discrimination than Whites, while for women, reports of lifetime discrimination are more similar among Brown and White respondents, with Black women reporting substantially more than other women. Men reported more discrimination than women across racial groups in Brazil, but the difference is larger and statistically 
Table 3

Percent reporting any lifetime discrimination, and count of respondents in each category by race, gender and educational attainment.

\begin{tabular}{|c|c|c|c|c|c|c|c|c|c|c|c|c|}
\hline & \multicolumn{4}{|c|}{ Less than high school } & \multicolumn{4}{|c|}{ High school or some college } & \multicolumn{4}{|c|}{ BA or more } \\
\hline & \multicolumn{2}{|c|}{ Women } & \multicolumn{2}{|c|}{ Men } & \multicolumn{2}{|c|}{ Women } & \multicolumn{2}{|c|}{ Men } & \multicolumn{2}{|c|}{ Women } & \multicolumn{2}{|c|}{ Men } \\
\hline & $\%$ & $n$ & $\%$ & $\mathbf{n}$ & $\%$ & $\mathbf{n}$ & $\%$ & $\mathbf{n}$ & $\%$ & $\mathbf{n}$ & $\%$ & $\mathbf{n}$ \\
\hline \multicolumn{13}{|c|}{ ELSA-Brasil $(\mathrm{N}=13,247)$} \\
\hline White & 29.1 & 206 & 34.0 * & 350 & $31.3 * \star$ & 1,065 & $37.4 * * *$ & 797 & $34.3 * *$ & 2,594 & $32.1 * * \star$ & 2,167 \\
\hline Brown & 31.2 & 282 & 36.9 & 425 & $34.6 * *$ & 855 & $41.7 * \star$ & 804 & $37.0 * *$ & 852 & $40.3 * \star$ & 613 \\
\hline Black & 36.0 * & 242 & $40.1 *$ & 279 & $43.1 *, \star \star$ & 735 & $53.0 *, * *$ & 413 & $59.3 *, * *$ & 383 & $60.0 *, * \star$ & 185 \\
\hline \multicolumn{13}{|c|}{$\operatorname{ACL}(N=1,680)$} \\
\hline White & 13.9 & 146 & $17.7 \star \star$ & 68 & $19.1 * *$ & 496 & $29.0 * *$ & 261 & 22.4 & 124 & $35.8 * \star$ & 147 \\
\hline Black & 16.4 * & 121 & $46.7 \star \star$ & 50 & $40.0 *, * *$ & 146 & $57.9 * *$ & 72 & 44.7 * & 33 & $73.6 * *$ & 16 \\
\hline
\end{tabular}

ACL: Americans' Changing Lives Study; BA: bachelor's degree; ELSA-Brasil: Brazilian Longitudinal Study of Adult Health.

* p-value < 0.05 in comparisons across education groups, within gender-by-race groups;

** $\mathrm{p}$-value $<0.05$ in comparisons across race groups, within gender-by-education groups.

significant for Black and Brown respondents only. The bottom panel of Table 2 for ACL respondents shows a similar pattern, with Black men and women significantly more likely to report lifetime discrimination than their White counterparts. For both Blacks and Whites, U.S. men were significantly more likely to report lifetime discrimination than U.S. women.

Table 3 presents a similar set of comparisons, now considering whether race-by-gender differences in perceived discrimination vary by educational attainment. In the ELSA sample, Black women and men show a significant positive association between level of education and perceived lifetime discrimination, while there is no significant difference across education levels for Brown men or women or White women. Among White Brazilian men, those with high school or some college were most likely to report lifetime discrimination, and those with a BA or more were least likely, although the magnitude of the difference is small. In the ACL sample, Black women and especially men showed a positive gradient in perceived discrimination with educational attainment, but due to small numbers of Black men, the pattern was not statistically significant for them. White men and women in the ACL showed a positive but nonsignificant gradient in perceived discrimination with educational attainment. Taken together, these results show that in most cases, more educated respondents are more likely to report lifetime discrimination, though White men in Brazil present an exception to this pattern. In both countries, differences across education levels are greater for Black than for White respondents, generating a larger race gap at higher levels of education that is often significant within gender-by-education groups.

Table 4 presents OR and 95\%CI from logistic regression models predicting any lifetime discrimination, with models for the ELSA-Brasil sample on the left side of the table and for ACL on the right. The first model includes race and gender as separate independent variables, and adjusts for age, while the second model further adjusts for educational attainment. This adjustment for education helps to show whether differences in education across groups account for any differences in discrimination associated with race or gender. The third model for each sample uses a categorical measure to capture intersectional race-by-gender groups, comparing each to White men, and the fourth model further adjusts for educational attainment.

Results for the Brazilian sample show that Brown (OR: 1.17; 95\%CI: 1.08-1.27) and Black (OR: 1.83; 95\%CI: 1.66-2.02) respondents are significantly more likely to report lifetime discrimination than Whites, net of gender and age, and that women are significantly less likely than men to do so (OR: 0.90; 95\%CI: 0.84-0.97). Older respondents are also less likely to report lifetime discrimination than younger, net of race and gender (OR: 0.98; 95\%CI: 0.98-0.99), probably due to cohort differences in awareness. While educational attainment is significantly and positively associated with reporting lifetime discrimination in the second model for ELSA-Brasil respondents, the pattern of association 
Odds ratios $(\mathrm{OR})$ and $95 \%$ confidence intervals $(95 \% \mathrm{Cl})$ for models predicting lifetime perceived discrimination.

\begin{tabular}{|c|c|c|c|c|c|c|c|c|}
\hline & \multicolumn{4}{|c|}{ ELSA-Brasil [OR $(95 \% \mathrm{Cl})]$} & \multicolumn{4}{|c|}{ ACL [OR $(95 \% \mathrm{CI})]$} \\
\hline & $\begin{array}{c}\begin{array}{c}\text { Main } \\
\text { effects }\end{array} \\
\text { of race \& } \\
\text { gender }\end{array}$ & $\begin{array}{c}\text { Main } \\
\text { effects + } \\
\text { education }\end{array}$ & $\begin{array}{l}\text { Race-by- } \\
\text { gender } \\
\text { category }\end{array}$ & $\begin{array}{l}\text { Race-by- } \\
\text { gender + } \\
\text { education }\end{array}$ & $\begin{array}{c}\text { Main } \\
\text { effects } \\
\text { of race \& } \\
\text { gender }\end{array}$ & $\begin{array}{c}\text { Main } \\
\text { effects + } \\
\text { education }\end{array}$ & $\begin{array}{l}\text { Race-by- } \\
\text { gender } \\
\text { category }\end{array}$ & $\begin{array}{l}\text { Race-by- } \\
\text { gender + } \\
\text { education }\end{array}$ \\
\hline \multicolumn{9}{|l|}{ Race [White omitted] } \\
\hline Brown & $\begin{array}{c}1.17 \\
(1.08-1.27)\end{array}$ & $\begin{array}{c}1.22 \\
(1.12-1.33)\end{array}$ & - & - & N/A & $N / A$ & N/A & N/A \\
\hline Black & $\begin{array}{c}1.83 \\
(1.66-2.02)\end{array}$ & $\begin{array}{c}1.94 \\
(1.75-2.15)\end{array}$ & - & - & $\begin{array}{c}2.53 \\
(1.89-3.38)\end{array}$ & $\begin{array}{c}2.77 \\
(2.04-3.76)\end{array}$ & - & - \\
\hline Female & $\begin{array}{c}0.90 \\
(0.84-0.97)\end{array}$ & $\begin{array}{c}0.89 \\
(0.83-0.95)\end{array}$ & - & - & $\begin{array}{c}0.57 \\
(0.44-0.76)\end{array}$ & $\begin{array}{c}0.58 \\
(0.44-0.77)\end{array}$ & - & - \\
\hline Age & $\begin{array}{c}0.98 \\
(0.98-0.99)\end{array}$ & $\begin{array}{c}0.98 \\
(0.98-0.99)\end{array}$ & $\begin{array}{c}0.98 \\
(0.98-0.99)\end{array}$ & $\begin{array}{c}0.98 \\
(0.98-0.99)\end{array}$ & $\begin{array}{c}0.96 \\
(0.95-0.97)\end{array}$ & $\begin{array}{c}0.97 \\
(0.96-0.98)\end{array}$ & $\begin{array}{c}0.96 \\
(0.95-0.97)\end{array}$ & $\begin{array}{c}0.97 \\
(0.96-0.98)\end{array}$ \\
\hline \multicolumn{9}{|l|}{$\begin{array}{l}\text { Educational } \\
\text { attainment [< high } \\
\text { school omitted] }\end{array}$} \\
\hline $\begin{array}{l}\text { High school/Some } \\
\text { college }\end{array}$ & - & $\begin{array}{c}1.14 \\
(1.01-1.28)\end{array}$ & - & $\begin{array}{c}1.14 \\
(1.01-1.29)\end{array}$ & - & $\begin{array}{c}1.48 \\
(0.97-2.27)\end{array}$ & - & $\begin{array}{c}1.48 \\
(0.96-2.27)\end{array}$ \\
\hline BA or more & - & $\begin{array}{c}1.24 \\
(1.10-1.39)\end{array}$ & - & $\begin{array}{c}1.25 \\
(1.11-1.41)\end{array}$ & - & $\begin{array}{c}1.82 \\
(1.11-3.00)\end{array}$ & - & $\begin{array}{c}1.83 \\
(1.11-3.01)\end{array}$ \\
\hline \multicolumn{9}{|l|}{$\begin{array}{l}\text { Race-by-gender } \\
\text { [White men omitted] }\end{array}$} \\
\hline White women & - & - & $\begin{array}{c}0.97 \\
(0.88-1.07)\end{array}$ & $\begin{array}{c}0.96 \\
(0.87-1.06)\end{array}$ & - & - & $\begin{array}{c}0.60 \\
(0.44-0.83)\end{array}$ & $\begin{array}{c}0.62 \\
(0.45-0.85)\end{array}$ \\
\hline Brown women & - & - & $\begin{array}{c}1.05 \\
(0.93-1.18)\end{array}$ & $\begin{array}{c}1.07 \\
(0.96-1.21)\end{array}$ & - & - & N/A & N/A \\
\hline Brown men & - & - & $\begin{array}{c}1.28 \\
(1.14-1.44)\end{array}$ & $\begin{array}{c}1.34 \\
(1.19-1.52)\end{array}$ & - & - & N/A & N/A \\
\hline Black women & - & - & $\begin{array}{c}1.68 \\
(1.47-1.91)\end{array}$ & $\begin{array}{c}1.76 \\
(1.54-2.00)\end{array}$ & - & - & $\begin{array}{c}1.21 \\
(0.83-1.78)\end{array}$ & $\begin{array}{c}1.36 \\
(0.91-2.02)\end{array}$ \\
\hline Black men & - & - & $\begin{array}{c}1.97 \\
(1.69-2.29)\end{array}$ & $\begin{array}{c}2.11 \\
(1.81-2.47)\end{array}$ & - & - & $\begin{array}{c}3.37 \\
(2.12-5.38)\end{array}$ & $\begin{array}{c}3.73 \\
(2.30-6.04)\end{array}$ \\
\hline N & 13,247 & 13,247 & 13,247 & 13,247 & 1,680 & 1,680 & 1,680 & 1,680 \\
\hline AIC & 17305 & 17250 & 17239 & 17214 & 2763 & 2753 & 2762 & 2751 \\
\hline
\end{tabular}

ACL: Americans' Changing Lives Study; AIC: Akaike Information Criterion; BA: bachelor's degree; ELSA-Brasil: Brazilian Longitudinal Study of Adult Health; N/A: not available.

found with race and gender does not change. In the third model for this Brazilian sample, Table 4 shows that Brown men (OR: 1.28; 95\%CI: 1.14-1.44), Black women (OR: 1.68; 95\%CI: 1.47-1.91) and Black men (OR: 1.97; 95\%CI: 1.69-2.29) are significantly more likely to report lifetime discrimination than White men, and adjusting for educational attainment in the fourth model does not substantively change these findings.

Results for U.S. adults in the right panel of Table 4 show that when considering the independent effects of race and gender, Blacks (OR: 2.53 ; 95\%CI: 1.89-3.38) are significantly more likely to report discrimination than Whites, and women (OR: $0.57 ; 95 \% \mathrm{CI}$ : 0.44-0.76) are less likely than men, with older respondents less likely to report discrimination (OR: 0.96; 95\%CI: 0.95-0.97). This pattern does not change with adjustment for educational attainment in the second model, though those with a 


\section{Table 5}

Odds ratios $(\mathrm{OR})$ and $95 \%$ confidence intervals $(95 \% \mathrm{Cl})$ for models predicting lifetime perceived discrimination by race-by-gender categories and educational attainment.

\begin{tabular}{|c|c|c|c|c|}
\hline & \multicolumn{2}{|c|}{ ELSA-Brasil } & \multicolumn{2}{|c|}{$A C L$} \\
\hline & OR & $95 \% \mathrm{Cl}$ & OR & $95 \% \mathrm{Cl}$ \\
\hline Age & 0.98 & 0.98-0.99 & 0.97 & $0.96-0.98$ \\
\hline \multicolumn{5}{|c|}{ Race+gender*education: < high school (White men: < high school) } \\
\hline White women: < high school & 0.84 & $0.57-1.21$ & 0.82 & $0.32-2.09$ \\
\hline Brown women: < high school & 0.91 & $0.65-1.28$ & - & - \\
\hline Brown men: < high school & 1.14 & $0.85-1.54$ & - & - \\
\hline Black women: < high school & 1.14 & $0.80-1.60$ & 1.01 & $0.39-2.63$ \\
\hline Black men: < high school & 1.31 & 0.94-1.82 & 4.68 & $1.77-12.41$ \\
\hline \multicolumn{5}{|c|}{ Race+gender*education: high school or some college (White men: high school or some college) } \\
\hline White women: high school or some college & 0.76 & 0.63-0.93 & 0.63 & $0.42-0.94$ \\
\hline Brown women: high school or some college & 1.18 & $0.96-1.44$ & - & - \\
\hline Brown men: high school or some college & 1.20 & $0.98-1.47$ & - & - \\
\hline Black women: high school or some college & 1.30 & $1.06-1.60$ & 1.54 & $0.92-2.56$ \\
\hline Black men: high school or some college & 1.91 & $1.50-2.43$ & 3.33 & $1.78-6.24$ \\
\hline \multicolumn{5}{|c|}{ Race+gender*education: BA or more (White men: BA or more) } \\
\hline White women: BA or more & 1.08 & $0.96-1.22$ & 0.52 & $0.28-0.99$ \\
\hline Brown women: BA or more & 1.18 & $1.00-1.39$ & - & - \\
\hline Brown men: BA or more & 1.34 & $1.11-1.61$ & - & - \\
\hline Black women: BA or more & 2.89 & $2.31-3.61$ & 1.61 & $0.60-4.32$ \\
\hline Black men: BA or more & 3.01 & $2.21-4.10$ & 4.74 & $1.12-19.96$ \\
\hline $\mathrm{AlC}$ & \multicolumn{2}{|c|}{17214} & \multicolumn{2}{|c|}{2759} \\
\hline
\end{tabular}

ACL: Americans' Changing Lives Study; AIC: Akaike Information Criterion; BA: bachelor's degree; ELSA-Brasil: Brazilian Longitudinal Study of Adult Health. Note: we calculated $\mathrm{OR}$ and $95 \% \mathrm{Cl}$ to compare the odds of reporting discrimination for other race-by-gender groups, compared to the odds for White men, among individuals with the same level of education. These were based on model that added an interaction term between educational category and race-by-gender category to the final models in Table 4 (not shown but available on request). For example, the OR for Black men with high school or some college compared to that for White men at the same level of education was calculated by exponentiating the sum of the coefficient for Black male and the coefficient of the interaction term for Black male*high school or some college.

BA or more are more likely to report lifetime discrimination than those with less than high school. The third model for ACL respondents shows that White women are significantly less likely (OR: 0.60; 95\%CI: 0.44-0.83) and Black men significantly more likely (OR: 3.37; 95\%CI: 2.12-5.38) to have perceived discrimination than White men, a pattern that does not change with the addition of educational attainment in the fourth model.

Table 5 tests whether race-by-gender differences in perceived discrimination differ across levels of education, controlling for respondent age and using OR. When considering respondents with less than a high school education in the top panel, the only significant difference is found between Black U.S. men (OR: 4.68; 95\%CI: 1.77-12.41) and White U.S. men. However, among respondents with a high school education or some college, shown in the middle panel, Black men (OR: 1.91; 95\%CI: 1.50-2.43) and women (OR: 1.30; 95\%CI: 1.06-1.60) in Brazil and Black men in the U.S. (OR: 3.33; 95\%CI: 1.78-6.24) have significantly higher odds of reporting lifetime discrimination than their White male counterparts. Among those with this middle level of education, White women in both Brazil (OR: 0.76; 95\%CI: 0.63-0.93) and the U.S. (OR: 0.63; 95\%CI: 0.42-0.94) have significantly lower odds of reporting lifetime discrimination. Among respondents with at least a bachelor's degree, in the bottom panel of Table 5, we find a slightly different pattern in the Brazilian sample, with Black men (OR: 3.01; 95\%CI: 2.21-4.10), Black women (OR: 2.89; 95\%CI: 2.31-3.61), Brown men (OR: 1.34; 95\%CI: 1.11-1.61) and Brown women (OR: 1.18; 95\%CI: 1.00-1.39) more likely to report lifetime discrimination than White men. The results for the most educated U.S. respondents are very similar 
to those for other levels of education: Black men (OR: 4.74; 95\%CI: 1.12-19.96) are significantly more likely and White women (OR: 0.52; 95\%CI: 0.28-0.99) significantly less likely to report lifetime discrimination than their White male counterparts.

\section{Discussion}

This study assessed perceived lifetime discrimination among Brazilian and U.S. adults, considering race differences and the way that these varied by gender. We also explored whether race-by-gender differences were explained by group differences in average levels of schooling, or if they varied across levels of education. The intersectional approach that we have used here considers race, gender, and socioeconomic position as mutually constitutive concepts, as opposed to separate "variables," and emphasizes these enmeshed identities as socially created by the historical and political processes from which they emerge 26 . Our comparison of Brazil and the United States, two multiracial societies with some key similarities but also very important differences in demography and social and legal histories $13,27,28$, allows us some leverage on the importance of different contexts that have shaped patterning of discrimination in each.

Using measures of lifetime discriminatory treatment from two large surveys, we found some similarities, chiefly that (1) Black respondents in both nations, and particularly Black men, were more likely to report lifetime discrimination, (2) White women generally were less likely to report it than White men, and (3) for most race-by-gender groups, perceived discrimination increased with education. Additionally, while educational attainment was positively associated with reports of discrimination and is differentially distributed by race and gender, adjusting for education did not explain race-by-gender group differences in either society. A positive association of perceived discrimination with education has been found in other studies 29 . Those with more education may be more aware of discriminatory treatment or more likely to identify it as such, or may engage in activities and move through social environments with a more diverse set of individuals, placing them at greater risk. In Brazil, Black individuals with more education and higher income are still seen to be "out of place" by some non-Blacks, and may feel that way, since social constructions historically have associated Blackness with lower status 30 .

There were also some important differences across countries. First, Brazil has a large population that identifies as Brown, due to historical policies aimed at "whitening" a population composed by a majority of Black people, while stricter racial segregation policies throughout earlier U.S. history restricted the growth of a group of mixed heritage people. We found that Brown Brazilian men and women reported higher levels of discrimination than White men, particularly among the more educated. Second, the most substantial differences in Brazil are found for Black men and women with high school or more, and for Brown men with a bachelor's degree or more, when compared with White men of similar education. This finding of sharper differentiation by race at higher levels of education is broadly consistent with a study of social mobility that showed racial differences only among more educated Brazilians 31. By contrast, U.S. Black men are uniquely disadvantaged regardless of education. The association between perceived discrimination and education also differs for White men across societies - Brazilian White men were unique among all groups in showing no difference in reports of discrimination by education. Brazilian scholars have debated whether race or social class are the basis of discriminatory treatment 28 , and U.S. scholars debate whether racial identity is no longer as relevant as socioeconomic status for understanding contemporary inequality 32 . Our results suggest that educational attainment may condition the influence of race-by-gender identities in both societies, but in distinctive ways that deserve further study.

Some key limitations should be considered when interpreting our results. The ELSA-Brasil and ACL samples differ in size and populations represented, with the larger ELSA study composed of civil servants, thus not capturing adults from the highest and lowest parts of the socioeconomic distribution of Brazil. Moreover, the ELSA sample better represents major urban centers in the South and Southeast than the northern and central parts of the country. The ACL represents the entire U.S. population, but is a smaller sample that was recruited to be representative in the mid-1980s, when the racial/ethnic composition was less diverse than now. Future studies can use more recent 
and representative data to better understand the evolving landscape of racial/ethnic, gender, and socioeconomic status inequality in perceived discrimination in both countries. Future work should also attempt to maximize comparability across samples by drawing on data collected using the same mode. We were limited to using telephone interview data from ACL respondents who were already accustomed to talking to interviewers in three prior in person or telephone interviews, whereas data from ELSA-Brasil respondents comes from their baseline, in-person interview, and these mode differences could have influenced how they reported about perceived discrimination. It would also be useful to consider how perceptions of discrimination change over time as social, political and legal conditions change, and a ways of talking about identities and discrimination change 33 , suggesting the importance of considering the specific cohort and period context in which discrimination was measured in each society being compared.

Both studies also rely on measures of lifetime discrimination in order to achieve comparability between samples, even though some have argued such measures may better capture men's experiences than women's 19 . Measures of everyday discrimination and hassles, as well as racism-related vigilance, are increasingly entering the literature 34 and should be included in future intersectional and comparative studies. Moreover, despite the similarity of the perceived discrimination measure, ELSABrasil asks about school and public spaces domains, while ACL does not ask about those domains, but includes more detailed questions about discrimination at work. Since we aggregate positive responses across domains to generate our measure of any lifetime discrimination, differences in domains or experiences captured could influence the accuracy of any comparisons across countries. Moreover, we created a relatively simple measure of "any" discriminatory experiences versus none. We did so to enhance comparability across countries and accommodate these variations in the survey instruments, and because we did not wish to make judgment calls about which combinations of domains (e.g. work, police) are more salient than others. Future studies could consider more conservative cut-points of exposure and different combinations of discriminatory experiences in multiple specific domains.

We also note three other important aspects of our measurement choices. First, we use a categorical measure of race in both societies, due to data availability, but recognize that there are important debates about the use of such categories versus use of skin tone measurements 35 . Future studies of perceived discrimination could evaluate race categories against skin color measures in different societies. Second, we use a two category measure of sex as an indicator of a much more complex construct of gender, due to the limitations of data available. However, gender identity and sexual orientation or identity may vary considerably within sex categories in ways that influence discriminatory experiences, and richer data are needed to consider these. Finally, we use education to indicate social class because its value is stable for most individuals over later adulthood, it is meaningful for all individuals regardless of their labor force status, and it is relatively comparable across societal contexts. However, social class is a complex construct, and other aspects, including those unique to particular societies, should be considered in future work. Moreover, we have grouped respondents into broad educational categories, and future work could disaggregate these and consider the importance of withingroup differences in credentials, occupational status, income or wealth, and other aspects of social class standing.

Despite these limitations, this study provides important new evidence for racial disparities in perceived lifetime discrimination that vary by gender in both Brazil and the United States. We have shown broad cross-national similarity in patterning, with greater likelihood of perceiving discrimination for Blacks in both societies, and a rise in the likelihood at higher levels of education that creates even greater racial gaps among the socioeconomically-advantaged. However, we also find important differences, such as the resilient and striking disadvantage of Black men in the U.S. at both high and low levels of education, as compared with the stronger findings for disadvantage among Brazilians of color, particularly men, at higher levels of education. These findings may be somewhat unexpected, given the particularly materially disadvantaged position of Black women in both societies, but it is important to recognize that gender differences within race groups may hold particular significance in intergroup relations in the U.S. and Brazil. It is also possible that measures of lifetime discrimination better capture experiences more salient for men ${ }^{19}$, suggesting the need for further research using alternative measurement strategies. Just as health policies should consider intersectional identities and experiences, these findings suggest that policies to decrease socioeconomic inequality should 
incorporate an awareness of intersectional inequalities in discriminatory experiences to ensure equal opportunities for all.

\section{Contributors}

S. Burgard and D. P. Castiglione contributed to the conceptualization of the paper, data analysis, interpretation and manuscript preparation. K. Y. Lin contributed to data analyses, interpretation and revision of final manuscript. A. A. Nobre contributed to data analyses and revision of final manuscript. E. M. L. Aquino, A. C. Pereira, I. J. M. Bensenor, and S. M. Barreto contributed to the fieldwork, data collection and revision of final manuscript. D. Chor contributed to the fieldwork, data collection, conceptualization of the paper, data analysis, and manuscript preparation.

\section{References}

1. Ahmed AT, Mohammed SA, Williams DR. Racial discrimination \& health: pathways \& evidence. Indian J Med Res 2007; 126:318-27.

2. Pascoe EA, Richman LS. Perceived discrimination and health: a meta-analytic review. Psychol Bull 2009; 135:531-54.

3. Williams DR, Gonzalez HM, Williams S, Mohammed SA, Moomal H, Stein DJ. Perceived discrimination, race and health in South Africa. Soc Sci Med 2008; 67:441-52.

\section{Acknowledgments}

The ELSA-Brasil was supported by the Brazilian Funding Authority for Studies and Projects (FINEP) and the Brazilian National Research Council (CNPq; grants 01060010.00 RS, 01060212.00 BA, 01060300.00 ES, 01060278.00 MG, 0106 0115.00SP, $01060071.00 \mathrm{RJ})$. D. C. is research fellow of CNPq (grant 303371/2014-5) and of FAPERJ (grant E26/201220/2014). The Americans' Changing Lives Study was supported by grant \# RO1AG018418 from the U.S. National Institute on Aging.
4. Macinko J, Mullachery P, Proietti FA, Lima-Costa MF. Who experiences discrimination in Brazil? Evidence from a large metropolitan region. Int J Equity Health 2012; 11:80.

5. Gonçalves H, Dumith SC, González DA, Menezes AMB, Araújo CLP, Hallal PC, et al. Discriminação autorrelatada por adolescentes de uma coorte de nascimentos brasileira: prevalência e associações. Rev Panam Salud Pública 2012; 31:204-10. 
6. Bastos JL, Barros AJD, Celeste RK, Paradies Y, Faerstein E. Age, class and race discrimination: their interactions and associations with mental health among Brazilian university students. Cad Saúde Pública 2014; 30:175-86.

7. Telles E. Pigmentocracies: ethnicity, race, and color in Latin America. Chapel Hill: UNC Press; 2014.

8. Kessler RC, Mickelson KD, Williams DR. The prevalence, distribution, and mental health correlates of perceived discrimination in the United States. J Health Soc Behav 1999; 40:208-30.

9. Williams DR, Yan Y, Jackson JS, Anderson NB. Racial differences in physical and mental health: socio-economic status, stress and discrimination. J Health Psychol 1997; 2:335-51.

10. Landrine $\mathrm{H}$, Klonoff EA. The schedule of racist events: a measure of racial discrimination and a study of its negative physical and mental health consequences. J Black Psychol 1996; 22:144-68.

11. D'Augelli AR, Hershberger SL. African American undergraduates on a predominantly white campus: academic factors, social networks, and campus climate. J Negro Educ 1993; 62:67-81.

12. Marx AW. Making race and nation: a comparison of South Africa, the United States, and Brazil. Cambridge: Cambridge University Press; 1998.

13. Telles EE. Racismo à brasileira: uma nova perspectiva sociológica. Rio de Janeiro: Editora RelumeDumará; 2003.

14. Guimarães ASA. Combatendo o racismo: Brasil, África do Sul e Estados Unidos. Rev Bras Ciênc Soc 1999; 14:103-17.

15. Harnois CE, Ifatunji M. Gendered measures, gendered models: toward an intersectional analysis of interpersonal racial discrimination. Ethn Racial Stud 2011; 34:1006-28.

16. Crenshaw KW. Demarginalising the intersection of race and sex: a black feminist critique of anti-discrimination doctrine, feminist theory, and anti-racist politics. In: Lutz H, Vivar MTH, Supik L, editors. Framing intersectionality: debates on a multi-faceted concept in gender studies. Surrey: Ashgate; 1989. p. 25-42.

17. Hirata H. Gênero, classe e raça: interseccionalidade e consubstancialidade das relações sociais. Tempo Social 2014; 26:61-73.

18. Sellers RM, Shelton JN. The role of racial identity in perceived racial discrimination. J Pers Soc Psychol 2003; 84:1079-92.

19. Ifatunji MA, Harnois CE. An explanation for the gender gap in perceptions of discrimination among African Americans: considering the role of gender bias in measurement. Sociol Race Ethn (Thousand Oaks) 2015; doi: 10.1177/2332649215613532.

20. Taylor TR, Williams CD, Makambi KH, Mouton C, Harrell JP, Cozier Y, et al. Racial discrimination and breast cancer incidence in US black women: the Black Women's Health Study. Am J Epidemiol 2007; 166:46-54.

21. Aquino EM, Barreto SM, Bensenor IM, Carvalho MS, Chor D, Duncan BB, et al. Brazilian Longitudinal Study of Adult Health (ELSA-Brasil): objectives and design. Am J Epidemiol 2012; 175:315-24.
22. Schmidt MI, Duncan BB, Mill JG, Lotufo PA, Chor D, Barreto SM, et al. Cohort profile: Longitudinal Study of Adult Health (ELSA-Brasil). Int J Epidemiol 2015; 44:68-75.

23. Chor D, Alves MGM, Giatti L, Cade NV, Nunes MA, Molina MCB, et al. Questionário do ELSA-Brasil: desafios na elaboração de instrumento multidimensional. Rev Saúde Pública 2013; 47:27-36.

24. Bensenor IM, Griep RH, Pinto KA, Faria CP, Felisbino-Mendes M, Caetano EI, et al. Rotinas de organização de exames e entrevistas no centro de investigação ELSA-Brasil. Rev Saúde Pública 2013; 47:37-47.

25. House JS, Lantz PM, Herd P. Continuity and change in the social stratification of aging and health over the life course: evidence from a nationally representative longitudinal study from 1986 to 2001/2002 (Americans' Changing Lives Study). J Gerontol B Psychol Sci Soc Sci 2005; 60(Special Issue 2):S15-26.

26. Schultz A, Mullings L. Gender, race, class and health: intersectional approaches. San Francisco: Jossey-Bass; 2006.

27. Jaccoud LO. O combate ao racismo e à desigualdade: o desafio das políticas públicas de promoção da igualdade racial. In: Theodoro M, editor. As políticas públicas e a desigualdade racial no Brasil, 120 anos após a abolição. Brasília: Instituto de Pesquisa Econômica Aplicada; 2008. p. 131-66.

28. Travassos C, Williams DR. The concept and measurement of race and their relationship to public health: a review focused on Brazil and the United States. Cad Saúde Pública 2004; 20:660-78.

29. Abramson CM, Hashemi M, Sánchez-Jankowski M. Perceived discrimination in U.S. healthcare: charting the effects of key social characteristics within and across racial groups. Prev Med Rep $2015 ; 2: 615-21$.

30. Figueiredo A. Fora do jogo: a experiência dos negros na classe média brasileira. Cadernos Pagu 2004; 23:199-228.

31. Ribeiro CAC. Classe, raça e mobilidade social no Brasil. Dados Rev Ciênc Soc 2006; 49:833-73.

32. Wilson WJ. New perspectives on the declining significance of race: a rejoinder. Ethn Racial Stud 2015; 38:1278-84.

33. Miranda V. A resurgence of black identity in Brazil? Evidence from an analysis of recent censuses. Demogr Res 2015; 32:1603-30.

34. Hicken MT, Lee H, Morenoff J, House JS, Williams DR. Racial/ethnic disparities in hypertension prevalence: reconsidering the role of chronic stress. Am J Public Health 2014; 104:117-23.

35. Bailey SR, Fialho FM, Penner AM. Interrogating race: color, racial categories, and class across the Americas. Am Behav Sci 2016; 60:538-55. 


\section{Resumo}

Há poucos estudos comparativos entre países sobre a experiência com a discriminação percebida, $e$ poucos examinaram a maneira pela qual as identidades interseccionais configuram a percepção do tratamento discriminatório nas diferentes sociedades. Com base em dados do ELSA-Brasil (um estudo de funcionários públicos brasileiros) e do Americans' Changing Lives Study (em uma amostra nacional representativa de adultos americanos), os autores comparam os relatos de grupos diferentes em relação à discriminação sofrida ao longo da vida, de acordo com raça e gênero, em cada sociedade. O estudo também investiga se o grau de escolaridade explica as diferenças entre grupos, ou se as diferenças dentro do mesmo grupo variam de acordo com a escolaridade. Os resultados mostram uma percepção maior de discriminação entre indivíduos negros em ambos os países, principalmente homens negros, comparado com brancos, além de menos relatos de discriminação sofrida por mulheres brancas comparado com homens brancos. No Brasil, mulheres e homens pardos relataram maiores niveis de discriminação em comparação com homens brancos. Com exceção de homens brancos, para todos os grupos analisados por raça e gênero, os relatos de discriminação foram mais frequentes entre os mais escolarizados, embora o ajuste por diferenças de escolaridade dentro dos grupos não explicasse as diferenças entre grupos. No Brasil, encontramos as maiores disparidades raciais entre individuos com nivel superior, enquanto nos Estados Unidos, os homens negros relatavam mais discriminação do que os homens brancos, independentemente de grau de escolaridade. Os resultados revelam semelhanças gerais entre os dois países, apesar de importantes diferenças históricas. A abordagem interseccional contribuiu para a identificação dessas semelhanças e de algumas diferenças nas experiências com a discriminação. Os achados do estudo têm implicações importantes para a vigilância social e sanitária, assim como, para intervenções voltadas ao enfrentamento das consequências danosas da discriminação.

Discriminação Social; Grupos Étnicos; Sexismo

\section{Resumen}

Existen pocos estudios comparativos entre países sobre la experiencia con la discriminación percibida, y pocos examinaron la manera mediante la cual las identidades interseccionales configuran la percepción del tratamiento discriminatorio en las diferentes sociedades. En base a los datos del ELSA-Brasil (un estudio de funcionarios públicos brasileños) y del Americans' Changing Lives Study (en una muestra nacional representativa de adultos americanos), los autores comparan los relatos de grupos diferentes, en relación a la discriminación sufrida a lo largo de la vida, de acuerdo con raza y género, en cada sociedad. El estudio también investiga si el grado de escolaridad explica las diferencias entre grupos, o si las diferencias dentro del mismo grupo varían de acuerdo con la escolaridad. Los resultados muestran una percepción mayor de discriminación entre individuos negros en ambos países, principalmente hombres negros, comparado con los blancos, además de menos relatos de discriminación sufrida por mujeres blancas, comparado con hombres blancos. En Brasil, mujeres y hombres mestizos relataron mayores niveles de discriminación, en comparación con los hombres blancos. Con excepción de hombres blancos, para todos los grupos analizados por raza y género, los relatos de discriminación fueron más frecuentes entre los más escolarizados, aunque el ajuste por diferencias de escolaridad dentro de los grupos no explicase las diferencias entre grupos. En Brasil, encontramos las mayores disparidades raciales entre individuos con nivel superior, mientras en los Estados Unidos, los hombres negros relataban más discriminación que los hombres blancos, independientemente del grado de escolaridad. Los resultados revelan semejanzas generales entre los dos países, a pesar de importantes diferencias históricas. El abordaje interseccional contribuyó a la identificación de esas semejanzas y de algunas diferencias en las experiencias con la discriminación. Los hallazgos del estudio tienen implicaciones importantes para la vigilancia social y sanitaria, así como, para intervenciones dirigidas a hacer frente a las consecuencias perniciosas de la discriminación.

Discriminación Social; Grupos Étnicos; Sexismo
Submitted on 30/Sep/2015

Final version resubmitted on 17/Mar/2016

Approved on 06/Apr/2016 